\title{
Implementation of the of Lifelong Learning Principles as a Background for Quality Specialized Education of Journalists
}

\author{
Yuriy M. Bidzilya ${ }^{1,}{ }^{*}$, Liubov M. Rusynko-Bombyk ${ }^{1}$, Yevhen O. Solomin $^{1}$, Hanna I. Hetsko $^{1} \&$ Olesya V. Barchan ${ }^{1}$ \\ ${ }^{1}$ Department of Journalism, Faculty of Philology, Uzhhorod National University, Uzhhorod, Ukraine \\ *Correspondence: Department of Journalism, Faculty of Philology, Uzhhorod National University, 3 Narodna \\ Square, 88000, Uzhhorod, Ukraine. E-mail: bidzilja@gmail.com
}

Received: December 7, 2021

Accepted: January 6, 2022 Online Published: January 17, 2022

doi:10.5430/jct.v11n1p142

URL: https://doi.org/10.5430/jct.v11n1p142

\begin{abstract}
The need for lifelong education is urged in the context of constant social transformations, unprecedented challenges, total digitalization of communicative transactions, virtualization of many types of professional activity. Journalism is one of the most sensitive to transformational challenges. Therefore, a journalist must respond objectively, flexibly, tolerantly, adequately, professionally, responsibly and social transformations and challenges to the current realities. To do this, he/she must be prepared for lifelong learning. It is the journalist's readiness for lifelong learning that is an indicator of the quality of his/her specialized education. The research aimed to empirically establish the skills of journalists related to lifelong learning, and to develop a programme for the implementation of the lifelong learning principles in the professional training of journalists. General scientific methods, surveys of research respondents, qualitative and quantitative analysis of the obtained data, modelling are the methods used. A model of modern journalist training in the context of lifelong learning was formed, a program for the implementation of lifelong learning principles in specialized education of journalists was developed. The results of the research can be used for the development of individual trainings, seminars, compilation of collections of didactic tools for the formation of the ability of modern journalists to education throughout life. Prospects for further research in this area are: experimental testing of our proposed program for the implementation of the principles of lifelong learning in the training of journalists; development of diagnostic tools to establish the levels of readiness of journalism students and practicing journalists for lifelong learning.
\end{abstract}

Keywords: educational institution, future specialists, journalist, education, quality of education

\section{Introduction}

Current educational transformations, changes in value priorities determine the need for constant improvement of knowledge, skills and abilities. The need to learn throughout life is an important prerequisite for sustainable professionalism in all branches of human activity. This urges the ability of any specialist to learn throughout life as one of the most important competencies of the representative of the society in the $21^{\text {st }}$ century. In order to form this key competence, it is necessary to organize a quality educational process at all levels of education.

Journalism is one of the activities which are the most integrated in society. It provides flexibility, mobility, readiness for constant change, requires an adequate response to instability and uncertainty, requires flexible skills, professional mobility, digital awareness. The modern journalist must be well-informed, educated, technically literate, objective, creative. In today's changing world, this can only be achieved through lifelong learning. Therefore, the implementation of the lifelong learning principles is important for the profession of journalist.

\subsection{Aims}

The aim of the research is to empirically establish skills in the content of professional training of journalists related to lifelong learning, and to develop a programme for the implementation of the lifelong learning principles in the education of journalists.

Research objectives: 
- analyse the state of knowledge on the problem of implementing the lifelong learning principles, as well as features, prospects and problems of specialized training of journalists in educational institutions;

- conduct an empirical study of the importance of journalists' skills related to lifelong learning;

- analyse the obtained empirical data, draw conclusions from the survey;

- compare the obtained results with the available foreign experience in the specified direction; establish common and distinctive features;

- draw conclusions about the correlation of quality specialized education of journalists and the implementation of lifelong learning;

- outline the prospects for further research within this problem.

The hypothesis of the study is that the basis for building the content of quality specialized education of journalists in the context of implementing the lifelong learning principles should be a consolidated vision of all stakeholders specialists, teachers and employers.

The scientific novelty of the research is the empirical determination of the components of the content of professional training of journalists related to lifelong learning, and the development of a programme for the implementation of the lifelong learning principles in the education of journalists.

\section{Literature Review}

Lifelong learning is often seen as a prerequisite for sustainable development (Webb et al., 2017), in the context of adult education (Gouthro, 2017; Hansen et al., 2019), motivated by "workforce aging" and the need to retransmit knowledge and experience, integration of all ways of learning (Formosa, 2019), self-determined learning (Blaschke, 2018), combining formal education, non-formal and informal learning as a means of guaranteeing rights and opportunities to all stakeholders, its positive impact on social life in general (Carr et al., 2018; Formosa, 2019). Scientists emphasize the need to increase the availability and quality of lifelong learning (Zagorodnya, 2018), seeing its main task in providing opportunities for all stakeholders to acquire the necessary knowledge, skills and abilities to implement social functions (Terenko, 2017).

Researchers are announcing increased accountability of learners and educational service providers for lifelong learning at all levels (Boeren, 2017). The prospects of lifelong learning are in its clear correlation with the ability to work effectively, run a business, build a full career based on self-acquisition of additional necessary knowledge, skills and abilities (Eppler-Hattab, 2021). Today, science has empirically confirmed the correlation between learning motivation, metacognitive factors and lifelong learning (Gogh \& Kovari, 2018); between lifelong learning and the transformation of awareness of this goal by the learner and the impact of educational institutions on this process (Talmage et al., 2018); between lifelong learning intentions and information literacy (Mbagwu, Chukwuedo \& Ogbuanya, 2020); adequately selected technologies to support the development of self-determined learning (Blaschke, 2018).

In the context of lifelong learning, the problem of using effective methods, the latest technologies, improving the access of learners to a variety of educational content, creating conditions for reflection need to be solved (Talmage et al., 2018). Besides, lifelong learning is a means of overcoming the passivity, colonization and marginalization of both learners and educators (Maitra \& Guo, 2019), sustainable development, providing inclusive and equitable quality education (Vargas, 2017). The effectiveness of lifelong learning is achieved by the optimal combination of varied creative ideas, methods, didactic tools for learning (Tatarinceva et al., 2018).

Researchers prove the effectiveness of lifelong learning in bridging the gap between workplace learning and professional education, pointing to the need to reconcile current learning pathways in education and future workplace learning (Nottingham, 2019), the complex relationship between adult learning and professional education (Hodge et. al., 2020). Lifelong learning is a kind of adequate response to the changing conditions of rapid civilizational progress, balancing the demands of the labour market in the knowledge society and educational service providers, a prerequisite for professional success, ensuring continuous and unlimited self-development based on rapid digital progress (Poplavskyi \& Bondar, 2021).

Science actively discusses effective forms of lifelong learning, such as educational camps, mass open online courses, portfolio use, fairy-tale games, research games, research cafes to achieve continuous advanced training and re-qualification. Achieving the effectiveness of lifelong learning is possible with a flexible approach, group and individual learning, integration of leisure, personal, professional activities, gamification (Poplavskyi \& Bondar, 
2021). The exceptional effectiveness in transforming the vision of lifelong learning is the integration of non-formal and informal learning in modern educational systems as a guarantee of sustainable development of society in the $21^{\text {st }}$ century (Kanwar, Balasubramanian \& Carr, 2019). This is confirmed by comprehensive studies of the effectiveness of implementation of the lifelong learning principles as a background for specialized education and actualization of the learners' need for further learning (Broiakovskyi et. al., 2020), in cultivating the concept of lifelong learning by the modern young generation on the basis of rapprochement and understanding of representatives of different generations (Lyu et al., 2020).

The understanding of the need to implement the principles of lifelong learning for journalists is motivated by the importance of academic specialized education of journalists (Ziani, Elareshi \& Al-Jaber, 2018), visual-centric conditions of professional journalism with the predominance of audio-visual media technologies (Nicolaou et al., 2021). Modernization of the content of specialized journalism education is also determined by the need to develop the instrumental competence of a journalist in the course of professional education (knowledge/skills related to mastering software, digital resources and technologies for creating and distributing media content) (Sytnyk, 2020).

Instilling the desire for continuous improvement of skills in journalists is confirmed by the variety of ways used by practicing journalists from different countries and cultures to expand the professionalism (Kus et al., 2016). The study confirmed the fact of a clear correlation between the level of professional training of journalists and their professional independence in conducting professional activities (Alonso, Moreira \& Amado, 2016), the level of critical perception of professional information. At the same time, empirical studies provide grounds to question the role of formal and informal professional socialization in the training of professional journalists (Vergeer 2018). This deepens the need to reconstruct or modernize journalism education, regularly stimulate and provide opportunities for journalists to learn throughout life (Vukić, 2020).

Among the main challenges of modern journalism education, researchers list the predominance in the content of education of journalists technical and technical component over the study of the impact of modern journalistic technologies on the target audience of recipients and their needs (Picard, 2015). Therefore, lifelong learning of journalists should be based on balancing technical skills and theoretical aspects (Narin, 2018), rethinking the understanding of journalism by the teaching community, developing and implementing virtual courses for critical thinking, independent learning and stimulating creativity and innovation of journalists (Mensing, 2017). This will contribute to the journalist's professional success, based on a productive combination of career project, individual choice, adaptability to labour market constraints and digital media opportunities (Pereira \& De Freitas Cardoso, 2021), competitiveness, as well as a high level of professionalism and professional responsibility (Diachenko, 2021).

The introduction of media education, training, management components (Belinskaya, 2020), development of critical thinking, social tolerance, fact-checking, visual literacy, innovation and creativity (Medynska, 2020), analytical thinking and communication skills (Martsikhiv, 2020) will contribute to the provision of high-quality specialized journalism education. The main condition for the successful implementation of the modernized content of journalism education is the consolidation of efforts, the vision of higher education institutions and the media market (Gabor, 2018).

Despite numerous studies that summarize theoretical and practical experience in lifelong learning and creating conditions for quality specialized education of journalists, the main components of the content of specialized journalism education within the principles of lifelong learning remain poorly covered in the scientific research. This is due to irrational approaches of educational institutions to the content of journalist training, disregard for the implementation of the lifelong learning principles, neglect of ongoing educational and social transformations related to education and journalism.

The analysed scientific literature urge the need for empirical establishment of the main vectors of lifelong learning within the professional training of journalists.

\section{Methods}

The study involved such methods as: general scientific methods, surveys of respondents, qualitative and quantitative analysis of the data, modelling to develop a programme for the implementation of the lifelong learning principles in the education of journalists. The study included the following stages: organizational and target - determining the purpose and objectives of scientific research; development of a questionnaire, determination of target audiences of respondents; inviting respondents to participate in the survey, obtaining consent to participate in the survey; empirical - conducting a survey of respondents, its analysis and results; development of a programme for the 
implementation of the lifelong learning principles in the specialized training of journalists; final - substantiation of the programme, drawing conclusions. The study was conducted from August to October 2021.

In order to take into account the leading positions of all stakeholders in the content of specialized training of journalists, the respondents of the study were: practicing journalists, teachers of higher educational institutions, representatives of the media market. All respondents were asked to assess the need for journalists to develop skills related to lifelong learning. These are such skills as: critical-analytical thinking, communicative skills, creativity, social tolerance, innovation, digital literacy, visual literacy, professional independence, professional responsibility, fact-checking. The respondents were asked to rate the need for journalists to have each of the ten skills on a scale of 0 to 3: $0-$ not significant, $1-$ low significance, $2-$ medium significance, $3-$ high significance. The questionnaire for respondents is given in the Appendix A.

\subsection{Sample}

Respondents were interviewed using Google forms. In order to organize the survey, e-mails were sent with the invitations for the administration of higher educational institutions and media groups to participate in the survey. The link for the survey was sent to the respondents who agreed to participate in it. Geography of respondents: Lviv, Kyiv, Dnipro, Odessa. Age of respondents: 25 - 50 years.

Respondents' education — basic higher (bachelor), full higher education (specialist, master), scientific degree - PhD in Educational Sciences, Philosophy, Dr of Educational Sciences, Dr of Philosophy. The survey covered 35 practicing journalists, 38 teachers of higher education institutions where the profession of journalist is available; 27 representatives of the media market (heads of regional media groups) who are employers of journalists.

\subsection{Intervention}

The survey was conducted for three months. The survey did not involve interference in the activities of respondents and was carried out only in their free time. The survey was conducted on a voluntary and anonymous basis. All respondents agreed to participate in the study.

\subsection{Research Limitations}

The sample is formed in such a way as to cover all those interested in lifelong learning in the field of journalism, that is journalists themselves, their employers and teachers of higher educational institutions involved in the preparation and implementation of the content of modern journalist training. The motives for the sampling involved:

1) the need to take into account the practicing journalists' vision of the quality of the obtained educational content and its correlation with the challenges of real work;

2) conducting an independent assessment of the significance of the content of education that the journalists obtained in the higher educational institution by employers in the industry;

3) establishing a real vision of the content of journalism education by the teaching community involved in the process of training journalists;

4) ascertaining or refuting the journalists' need for additional competencies, expanding the range of skills acquired during specialized training in higher educational institution.

\section{Results}

The research was conducted in three groups of respondents: journalists, heads of media companies, teachers of higher educational institutions. All respondents were asked to assess the importance of such diagnostic constructs as the journalist's skills, which he/she must develop within lifelong learning. These are critical-analytical thinking, communicative skills, creativity, social tolerance, innovation, digital literacy, visual literacy, professional independence, professional responsibility, fact-checking.

The results of the survey of all three groups of respondents in percent are summarized in Tables 1-3. 
Table 1. Results of the Journalists' Survey

\begin{tabular}{lcccc}
\hline \multirow{2}{*}{ Skills } & \multicolumn{4}{c}{ Significance } \\
\cline { 2 - 5 } & not significant & low & medium & high \\
\hline critical-analytical thinking & 15 & 15 & 30 & 40 \\
communicative skills & - & 15 & 45 & 40 \\
creativity & - & 10 & 40 & 50 \\
social tolerance & 20 & 20 & 30 & 30 \\
innovation & - & 40 & 30 & 30 \\
digital literacy & - & 40 & 30 & 30 \\
visual literacy & - & 50 & 20 & 30 \\
professional independence & - & - & 50 & 50 \\
professional responsibility & - & - & 50 & 50 \\
fact-checking & $\mathbf{1 0}$ & $\mathbf{1 5}$ & $\mathbf{4 0}$ & $\mathbf{2 5}$ \\
\hline
\end{tabular}

The data of practicing journalists' surveys presented in Table 1 testify to the prevalence in their understanding of the profession of such skills as: creativity, professional independence, professional responsibility, critical-analytical thinking, communicative skills. This shows that journalists understand their work as a creative, critically meaningful communicative process, which they implement independently with a high degree of responsibility. Therefore, practicing journalists consider it appropriate to develop creativity throughout life as a skill that enables generation of new creative ideas. The communication skills allow journalists to achieve successful communication with all target actors. It is commendable that journalists strive for independence in their activities and understand the high advance of responsibility imposed on them. That is why they strive to develop such skills within lifelong learning. However, the respondents in the current study clearly underestimate the importance of $21^{\text {st }}$-century skills, such as social tolerance and fact-checking. They took them to the background. But it is these skills that make it possible to achieve objectivity, independence and humanity in journalism.

Table 2. Results of the Survey of Media Executives

\begin{tabular}{lcccc}
\hline \multirow{2}{*}{ Skills } & \multicolumn{4}{c}{ Significance } \\
\cline { 2 - 5 } & not significant & low & medium & high \\
\hline critical-analytical thinking & - & 5 & 45 & 50 \\
communicative skills & - & 55 & 35 & 10 \\
creativity & - & - & 55 & 45 \\
social tolerance & - & 40 & 60 & - \\
innovation & - & 60 & 40 & - \\
digital literacy & 10 & 30 & 30 & 25 \\
visual literacy & 25 & 25 & 25 & 70 \\
professional independence & - & - & 30 & 80 \\
professional responsibility & - & - & 20 & $\mathbf{4 0}$ \\
fact-checking & - & - & $\mathbf{6 0}$ & \\
\hline
\end{tabular}

According to the data from the survey of media company executives presented in Table 2, employers of modern journalists especially value such skills of their subordinates as professional responsibility and professional independence. They are unanimous on this issue with the journalist respondents, who also rate these two skills high. Critical-analytical thinking, creativity and fact-checking are essential for employers in the journalism market. This demonstrates the desire of media executives to see their subordinates as independent, responsible, creative, critical, capable of analysing broadcast content, free from intrusive influence and pressure, and objective professionals. 
Table 3. Results of the Survey of Heads and Teachers of Higher Educational Institutions

\begin{tabular}{lcccc}
\hline \multirow{2}{*}{ Skills } & \multicolumn{4}{c}{ Significance } \\
\cline { 2 - 5 } & not significant & low & medium & high \\
\hline critical-analytical thinking & - & - & 20 & 80 \\
communicative skills & - & - & 70 & 30 \\
creativity & - & - & 10 & 90 \\
social tolerance & - & - & 60 & 40 \\
innovation & - & - & 70 & 30 \\
digital literacy & - & 20 & 40 & 40 \\
visual literacy & - & 20 & 40 & 40 \\
professional independence & - & - & 20 & 80 \\
professional responsibility & - & - & 60 & 40 \\
fact-checking & - & - & $\mathbf{2 0}$ & $\mathbf{8 0}$ \\
\hline
\end{tabular}

According to the data in Table 3, it can be stated that teachers of educational institutions that teach journalists consider the following skills to be the most important for improvement throughout life: creativity, critical-analytical thinking, professional independence, fact-checking. This gives grounds to state that, from the teachers' perspective, a modern journalist should be a creative, thinking, capable of analysis, professionally independent, objective, stable personality.

The generalization of the survey data of journalists, teachers, managers of media companies allows developing a model of training a modern journalist in the context of lifelong learning (Figure 1). This model reflects the consolidation of the views of all stakeholders. According to this model, a modern journalist must first develop and improve such skills as creativity, professional responsibility and independence, fact-checking within lifelong learning. Modern journalist should pay less attention to the development of such important skills as innovation, communication skills, social tolerance in the context of lifelong learning. The journalists' skills of visual and digital literacy are little significant today.

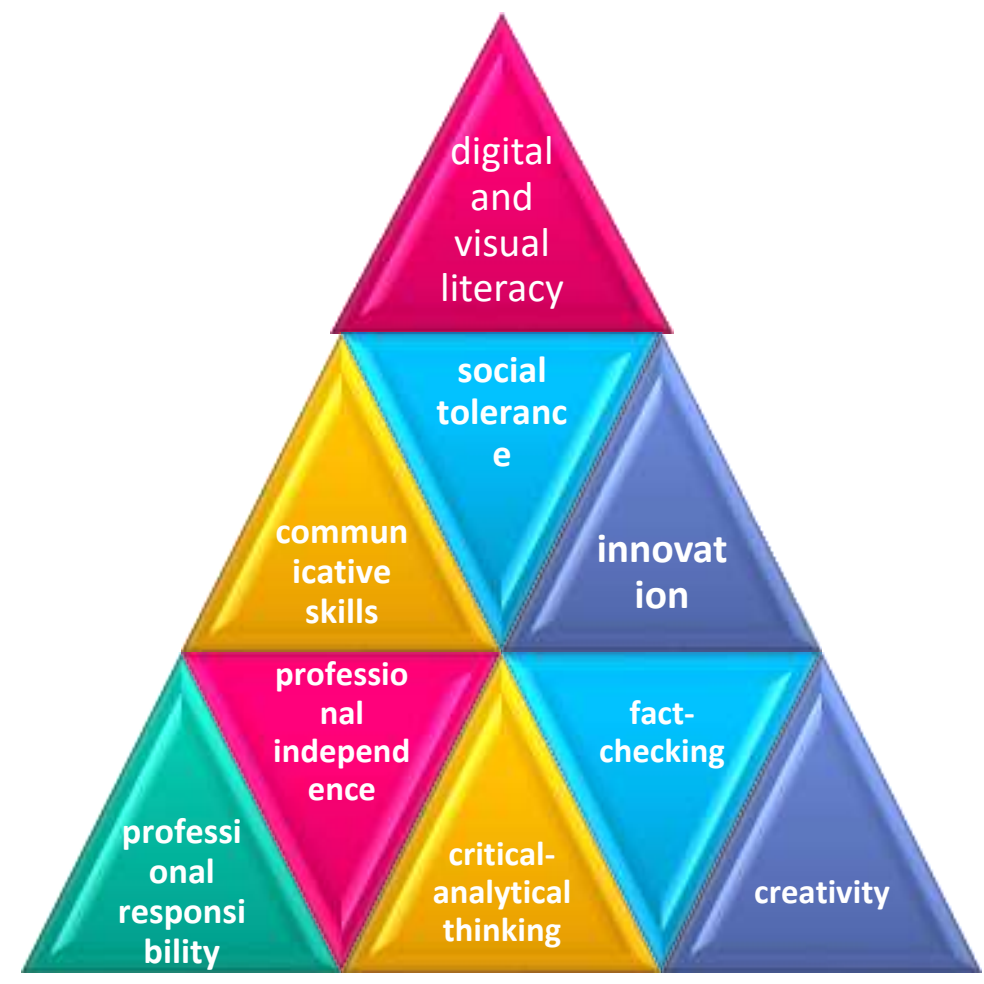

Figure 1. Journalist's Lifelong Learning Model 
Table 4. The Programme of the Implementation of Lifelong Learning Principles in Specialized Education of Journalists

\begin{tabular}{|c|c|c|c|}
\hline Item No. & Skills & Activities & Indicative events \\
\hline 1 & Critical-analytical thinkj & $\begin{array}{l}\text { Conducting thinking development } \\
\text { trainings }\end{array}$ & $\begin{array}{l}\text { 1. } \quad \text { Training "Journalist and Thinking". } \\
\text { 2. Training "Work meaningfully". }\end{array}$ \\
\hline 2 & Communicative skills & $\begin{array}{l}\text { Conducting role-playing games, } \\
\text { trainings with reframing elements, } \\
\text { solving communicative dilemmas }\end{array}$ & $\begin{array}{l}\text { 1. Role-playing game "Journalist-target } \\
\text { community" } \\
\text { 2. Training with the elements of reframing } \\
\text { "Another view of the situation". } \\
\text { 3. Communicative battle "Solve the dilemma" }\end{array}$ \\
\hline 3 & Creativity & Organization of professional quests & $\begin{array}{l}\text { 1. Professional quest "News Labyrinth". } \\
\text { 2. Professional quest "Catch the } \\
\text { reader's/viewer's interest". }\end{array}$ \\
\hline 4 & Social tolerance & $\begin{array}{l}\text { Conducting seminars and training } \\
\text { sessions }\end{array}$ & $\begin{array}{l}\text { 3. Discussion "Should a journalist be } \\
\text { tolerant?" } \\
\text { 4. } \begin{array}{l}\text { Creative project "Prospects of journalistic } \\
\text { tolerance" }\end{array} \\
\text { 5. Seminar "Developing tolerance" } \\
\text { 6. Storytelling "Me and tolerance" }\end{array}$ \\
\hline 5 & Innovation & Organization of project activities & $\begin{array}{l}\text { 1. Group project "Me and the media" } \\
\text { 2. Individual project "Journalist - target } \\
\text { audience: means of activating interest" }\end{array}$ \\
\hline 6 & Digital literacy & $\begin{array}{l}\text { Conducting training seminars, } \\
\text { participation in project activities }\end{array}$ & $\begin{array}{l}\text { 1. Group project "My media resource" } \\
\text { 2. Individual project "My blogosphere" } \\
\text { 3. Training seminar "Digital ethics and } \\
\text { security" }\end{array}$ \\
\hline 7 & Visual literacy & $\begin{array}{l}\text { Conducting mini-modelling, content } \\
\text { analysis of electronic publications, } \\
\text { discussions, research projects }\end{array}$ & $\begin{array}{l}\text { 1. Content analysis "Visual value of modern } \\
\text { publications" } \\
\text { 2. Mini-modelling "Algorithm for the } \\
\text { development of my visual skills" } \\
\text { 3. Discussion "The impact of visual design of } \\
\text { journalistic content on target audiences" } \\
\text { 4esearch project-survey of target audiences } \\
\text { "Does the visual design of journalistic } \\
\text { materials matter" }\end{array}$ \\
\hline 8 & $\begin{array}{l}\text { Professional } \\
\text { independence }\end{array}$ & $\begin{array}{l}\text { Analysis of professional situations, } \\
\text { completion of advanced } \\
\text { problem-solving assignments, game } \\
\text { technology }\end{array}$ & $\begin{array}{l}\text { 1. Research assignment "Steps to perfect } \\
\text { content" } \\
\text { 2. Individual assignment "Create an original } \\
\text { publication" } \\
\text { 3. Game-competition "My post". }\end{array}$ \\
\hline 9 & $\begin{array}{l}\text { Professional } \\
\text { responsibility }\end{array}$ & $\begin{array}{l}\text { Development and showing of } \\
\text { motivational videos, analysis of } \\
\text { professional situations }\end{array}$ & $\begin{array}{l}\text { 1. Analysis of a video selection of } \\
\text { professional situations. } \\
\text { 2. Creating an amateur video "Journalist and } \\
\text { responsibility" }\end{array}$ \\
\hline 10 & Fact-checking & $\begin{array}{l}\text { Training seminars, use of interactive } \\
\text { exercises, analysis of professional } \\
\text { situations, analysis of the content of } \\
\text { media publications }\end{array}$ & $\begin{array}{l}\text { 1. Training seminar "Signs and criteria of } \\
\text { false information" } \\
\text { 2. Analysis of the content of publications for } \\
\text { flakiness } \\
\text { 3. Interactive exercises "Truth or fake" }\end{array}$ \\
\hline
\end{tabular}


Based on the consolidated model of lifelong education of journalists, we have developed a programme for the implementation of the lifelong learning principles in the professional training of journalists. The programme takes into account the vision of quality specialized education of journalists by all stakeholders. The programme can be implemented in the educational process of training journalists in higher educational institutions of Ukraine.

The implementation of the proposed programme will help improve the skills of students majoring in journalism and increase their readiness for lifelong learning.

\section{Discussion}

The study provided sound insights to understand the content of quality professional education of journalists within the lifelong learning of all stakeholders: journalists themselves, their employers and teachers who deliver the content of journalism education. The researches which are similar to ours confirm the need to direct the subjects of the educational process to improve information literacy skills, develop self-study skills, which is crucial in the context of lifelong learning (Mbagwu, Chukwuedo \& Ogbuanya, 2020), the reasonability of introduction of effective pedagogical methods, technologies, interactivity at realization of lifelong learning principles is urged (Talmage et al., 2018), overcoming the imbalance between economic and social vectors of lifelong learning, the reorientation of education from market priorities to public ones is emphasized (Vargas, 2017).

Empirical research also proves the importance of establishing a clear set of new competencies, stimulating personal self-development within lifelong learning and developing students' readiness for lifelong learning as an important prerequisite for professional success (Poplavskyi \& Bondar, 2021), continuous training and retraining throughout life, state the imperfection of traditional educational systems in relation to the development of lifelong learning skills (Kanwar, Balasubramanian \& Carr, 2019).

The following studies are related to the topic of our research concept of the study, which aimed to determine the quality of our education in relation to the challenges of professional activity on the basis of a survey of students majoring in journalism and practicing journalists (Ziani, Elareshi \& Al-Jaber, 2018), establishment of three directions of development of specialized education of journalists (orientation, values and standards of journalism; social, cultural, political, economic, legal, ethical aspects; knowledge and intellectual component) (Martsikhiv, 2020), establishment of features of realization of the continuous training principles and definition of the specialists' need for additional competencies (Broiakovskyi et al., 2020).

Similarly to our study, the emphasis is on the reasonability of conducting a survey of subjects of the educational process to establish motives for lifelong learning (Gogh \& Kovari, 2018), to establish compliance with the content of specialized education of journalists with the main challenges of professional activity (Ziani, Elareshi \& Al-Jaber, 2018).

The study confirmed the need to adjust and harmonize the current content of education and job prospects (Nottingham, 2019), which ensures the continuity of specialized education and serves as an indicator of its quality. It is also important to find mechanisms to maintain a balance between academic knowledge and technological skills in journalism education programmes, which primarily requires the study of positive experiences of modernization of journalism education (Sytnyk, 2020). The fact of correlation between professional independence of journalists and their level of education is empirically confirmed (Alonso, Moreira, S.V., \& Amado, 2016), intentions are expressed on studying the correlation of journalists' level of education and their ability to fact-check (Vukić, 2020). According to our survey, professional independence and fact-checking are of great importance in the implementation of the lifelong learning principles.

The main research, which is different from ours, is the one proving the effectiveness of the use of audio-visual content in the specialized journalism education (Nicolaou et. al., 2021). We believe that the implementation of the content of specialized journalism education can delivered through the use of a high level of audiovisualization, but this is not the main thing. The main thing is the complex content of specialized education of journalists in the context of developing lifelong learning skills. This content should be based on consolidating the vision of all stakeholders (students, pedagogical communities, employers in the industry).

A different vision of the content of specialized education of journalists from the concept of our study is scientific research on the importance of developing the instrumental competence of a journalist in the course of professional training (Sytnyk, 2020). However, our survey shows the low importance of purely instrumental skills of journalists in the implementation of the lifelong learning principles. 
The similarity of a number of scientific studies with our study is confirming the need to take into account the positions of all stakeholders in developing the content of specialized education of journalists, which reflects not only the professional level of training, but also the foundation of motivation and willingness to improve skills throughout life.

However, in most similar studies the main emphasis is on the need to modernize the content of specialized education of journalists. But such an insight was not supported by scientifically and methodologically sound practices of producing the content of journalists' education, taking into account the lifelong learning principles.

The main difference between the concept of our study and similar ones is in establishing clear visions of all stakeholders (teachers, employers, trained personnel) on the range of skills that a journalist should have, as well as the process of improvement of which is extended throughout life.

This empirical study of the importance of journalists' skills related to lifelong learning, and a comparison of the results obtained with existing foreign experience in this area demonstrates the correlation of quality specialized education of journalists and the implementation of lifelong learning, as well as the reasonability of building the content of quality specialized education of journalists in the context of implementing the lifelong learning principles based on a consolidated vision of all stakeholders - the representative of the profession, teachers and employers.

The conducted research gives grounds to express intentions for establishing the vision of target audiences (readers, viewers, listeners) on the skills of journalists that should be improved throughout life. The study of the correlation between the journalists' skills and the effectiveness of their work throughout their professional careers, between skills and professional success, the impact of skills on the career achievements of journalists is of particular scientific interest.

\section{Conclusions}

The study raises the topical issue of lifelong learning in the context of quality specialized education of journalists. The survey of practicing journalists, teachers, employers of the media, organized within the scientific research, assessed the importance of scientifically sound skills of a journalist that need to be improved in the context of lifelong learning. These are critical-analytical thinking, communicative skills, creativity, social tolerance, innovation, digital literacy, visual literacy, professional independence, professional responsibility, fact-checking.

The study found high importance of the following skills of journalists in the lifelong learning: creativity, professional independence, professional responsibility, critical and analytical thinking, communicative skills (vision of practicing journalists); creativity, critical-analytical thinking, professional independence, fact-checking (teachers' vision), professional responsibility, professional independence, critical-analytical thinking, creativity, fact-checking (media employers' vision).

The results of the research confirmed the hypothesis that the basis for building the content of quality specialized education of journalists in the context of implementing the lifelong learning principles should be a consolidated vision of all stakeholders - representative of the professional, teachers and employers.

The obtained empirical data allowed building an author's model of lifelong journalism education, which reflects the gradational significance of skills to be improved by a journalist in the implementation of lifelong learning principles: highly significant skills — creativity, professional responsibility and independence, fact-checking, medium significance - innovation, communication skills, social tolerance, little significant — journalists' visual and digital literacy skills.

We developed a programme for the implementation of the lifelong learning principles in the education of journalists based on the consolidated model of lifelong learning of journalists. It takes into account the vision of quality specialized education of journalists by all stakeholders. The programme can be implemented in the educational process of training journalists in higher educational institutions of Ukraine. The programme provides training, situational, interactive exercises, creative and project activities, elements of reframing, content analysis, modelling.

Empirically obtained research results can be used to develop individual trainings, seminars, preparing the collections of didactic tools for the development of modern journalist's skills in the context of lifelong learning. It is the adequate programming of the content of the journalists' specialized education that ensures their readiness for lifelong learning.

The prospects for further scientific research in this area include: search, development, testing and implementation of effective methods, techniques, forms of work on the development of skills to be improved throughout life in the 
course of specialized training of journalists; experimental approbation of the programme that we proposed for the implementation of the lifelong learning principles in the training of journalists; development of diagnostic tools to establish the levels of readiness of journalism students and practicing journalists for lifelong learning.

\section{References}

Alonso, M. O., Moreira, S. V., \& Amado, A. (2016). The relationship between the education of journalists and their perception of autonomy. Results of the Worlds of Journalism Study (WJS) in South America: Argentina, Brazil and Ecuador. Paper presented at the World Journalism Education Conference. Identity and integrity in journalism education (14/07/16) at the Victoria University of Wellington (Auckland, New Zealand). Retrieved from https://www.researchgate.net/publication/323772602_The_relationship_between_the_education_of_journalists and_their_perception_of_autonomy_Results_of_the_Worlds_of_Journalism_Study_WJS_in_South_America_A rgentina_Brazil_and_Ecuador

Belinskaya, I. V. (2020). Cybersocialization in the context of professional training of future journalists. In: Cybersocialization. Collection of scientific works (pp. 6-9). Kropyvnytskyi, Ukraine: Imex-LTD.

Blaschke, L. M. (2018). Self-determined learning (heutagogy) and digital media creating integrated educational environments for developing lifelong learning skills. In: Kergel D., Heidkamp B., Telléus P., Rachwal T., \& Nowakowski S. (Eds.), The digital turn in higher education (pp. 129-140). Wiesbaden, Germany: Springer VS. https://doi.org/10.1007/978-3-658-19925-8_10

Boeren, E. (2017). Understanding adult lifelong learning participation as a layered problem. Studies in Continuing Education, 39(2), 161-175. https://doi.org/10.1080/0158037X.2017.1310096

Broiakovskyi, O. V., Ilchuk, V. V., Mas, N. M., Kapinus, O. S., \& Okaievych, A. V. (2020). The implementation of the principles of lifelong learning as the basis of quality specialize education. International Journal of Higher Education, 9(7), 12-23. https://doi.org/10.5430/ijhe.v9n7p12

Carr, A., Balasubramanian, K., Atieno, R., \& Onyango, J. (2018). Lifelong learning to empowerment: beyond formal education. Distance Education, 39(1), 69-86. https://doi.org/10.1080/01587919.2017.1419819.

Diachenko, M. D. (2021). Professional responsibility in the context of forming the professionalism of future journalists. Scientific Journal of National Pedagogic Dragomanov University, 81, 77-82. https://doi.org/10.31392/NPU-nc.series5.2021.81.17

Eppler-Hattab, R. (2021). From lifelong learning to later life self-employment: a conceptual framework and an Israeli enterprise perspective. Journal of Enterprising Communities: People and Places in the Global Economy (Ahead of print). https://doi.org/10.1108/JEC-01-2021-0014

Formosa, M. (2019). Active ageing through lifelong learning: the university of the third age. In: International perspectives on aging (vol. 23, pp 3-18). Cham, Switzerland: Springer. https://doi.org/10.1007/978-3-030-21515-6_1

Gabor, N. (2018). Journalism education of the WEB.3.0 era: research, new skills, reboot attempts. Lviv National University Herald, 43, 273-279.

Gogh, E., \& Kovari, A. (2018). Metacognition and Lifelong Learning: A survey of secondary school students. In: P. Baranyi (Ed.), 9th IEEE International Conference on Cognitive Infocommunications (CogInfoCom) (pp. 271-276). https://doi.org/10.1109/CogInfoCom.2018.8639961

Gouthro, P. A. (2017). The promise of lifelong learning. International Journal of Lifelong Education, 36(1-2), 45-59. https://doi.org/10.1080/02601370.2017.1270067

Hansen, R. J., Talmage, C. A, Thaxton, S. P., \& Knopf, R. C. (2019). Barriers to age-friendly universities (AFU): Lessons from Osher Lifelong Learning Institute demographics and perceptions. Gerontology \& Geriatrics Education, 40(2), 221-243. https://doi.org/10.1080/02701960.2019.1572003

Hodge, S., Holford, J., Milana, M., Waller, R., \& Webb, S. (2020). Adult education, vocational education and economic policy: theory illuminates understanding. International Journal of Lifelong Education, 39(2), 133-138. https://doi.org/10.1080/02601370.2020.1747791 
Kanwar, A., Balasubramanian, K., \& Carr, A. (2019). Changing the TVET paradigm: new models for lifelong learning. International Journal of Training Research, 17(S1), 54-68. https://doi.org/10.1080/14480220.2019.1629722

Kus, M., Eberwein, T., Porlezza, C., \& Splendore, S. (2016). Training or improvisation? Citizen journalists and their educational backgrounds -a comparative view. Journalism Practice, 11(2-3), 355-372. https://doi.org/10.1080/17512786.2016.1221737

Lyu, K., Xu, Y., Cheng, H., \& Li, J. (2020). The implementation and effectiveness of intergenerational learning during the COVID-19 pandemic: Evidence from China. International Review of Education, 66, 833-855. https://doi.org/10.1007/s11159-020-09877-4

Maitra, S., \& Guo, S. (2019). Theorising decolonisation in the context of lifelong learning and transnational migration: anti-colonial and anti-racist perspectives. International Journal of Lifelong Education, 38(1), 5-19. https://doi.org/10.1080/02601370.2018.1561533

Martsikhiv, K. (2020). Formation of skills, knowledge and values in the process of professional training of future journalists at US universities. Imidzh Suchasnoho Pedahoha, 3(192), 31-35. https://doi.org/10.33272/2522-9729-2020-3-192-31-35

Mbagwu, F. O., Chukwuedo, S. O., \& Ogbuanya, T. C. (2020). Promoting lifelong learning propensity and intentions for vocational training among adult and vocational educational undergraduates. Vocations and Learning, 13, 419-437. https://doi.org/10.1007/s12186-020-09245-1

Medynska, O. Y. (2020). Media competence as a component of professional training of future journalists. In: O. M. Petrovsky et al. (Eds.), Development of professional skills of a teacher in the new socio-cultural reality: Proceedings of the III International Scientific and Practical Conference (Ternopil, Ukraine, April 09-10, 2020) (pp. 231-235). Ternopil, Ukraine: SMP "Type".

Mensing, D. (2017). The curious case of U.S. journalism education: shrinking newsrooms, expanding classrooms. In: R. S. Goodman, \& E. Steyn (Eds.), Global journalism education in the 21st century: challenges and innovations (pp. 219-242). Austin, TX: Knight Center for Journalism in the Americas.

Narin, B. (2018). Teaching high tech storytelling: reorganizing journalism education for programmer journalists and data journalists. In: M. Lòpez-Paredes (Ed.), Nuevos escenarios de la comunicación: retos y convergencias [New communication scenarios: challenges and convergences] (pp. 169-195). Quito, Ecuador: Pontificia Universidad Católica del Ecuador.

Nicolaou, C., Matsiola, M., Karypidou, C., Podara, A., Kotsakis, R., \& Kalliris, G. (2021). Media studies, audiovisual media communications, and generations: the case of budding journalists in radio courses in Greece. Journal. Media, 2, 155-192. https://doi.org/10.3390/journalmedia2020010

Nottingham, P. (2019). Acknowledging lifelong learning principles within work-based studies: a continuing legacy for the degree apprenticeship. Widening Participation and Lifelong Learning, 21(1), 29-45. https://doi.org/10.5456/WPLL.21.1.29

Pereira, F. H., \& De Freitas Cardoso, J. (2021). Professional digital journalists and entry in the Portuguese labour market. Media Practice and Education, 22(3), 225-238. https://doi.org/10.1080/25741136.2021.1904616

Picard, R. G. (2015). Deficient tutelage: challenges of contemporary journalism education. Retrieved from http://www.robertpicard.net/files/Picard_deficient_tutelage.pdf

Poplavskyi, M., \& Bondar, I. (2021). Application of information technologies for lifelong learning. International Journal of Computer Science and Network Security, 21(6), 304-311.

Sytnyk, O. (2020). Instrumental competence of journalists as one of the main educational results of their professional training. Current Issues of Mass Communication, 27, 21-30. https://doi.org/10.17721/2312-5160.2020.27.21-30

Talmage, C. A., Hanson, R. J., Knopf, R. C., \& Thaxton, S. P. (2018). Directions for 21st century lifelong learning institutes: elucidating questions from osher lifelong learning institute studies. Alberta Journal of Educational Research, 64(2), 109-125.

Tatarinceva, A. M., Sergeeva, M. G., Dmitrichenkova, S. V., Chauzova, V. A., Andryushchenko, I. S., \& Shaleeva, E. F. (2018). Lifelong learning of gifted and talented students. Espacios, 39(2), 29. 
Terenko, O. O. (2017). Conceptual ideas on adult education in Canadian pedagogy. Pedahohika Formuvannya Tvorchoyi Osobystosti u Vyshchiy i Zahal'noosvitniy Shkolakh, 55, 341-347.

Vargas, C. (2017). Lifelong learning from a social justice perspective. Retrieved from https://www.right-to-education.org/sites/right-to-education.org/files/resource-attachments/Unesco_Lifelong_lea rning_from_a_social_justice_perspective_2017_En.pdf

Vergeer, M. (2018). Incorrect, fake, and false. Journalists' perceived online source credibility and verification behavior. Observatorio Journal, 12(1), 38-52. https://doi.org/10.15847/obsOBS12120181126

Vukić, T. (2020). Journalism education and fake news: a literature review. Medij. Istraž, 26(2), 77-99. https://doi.org/10.22572/mi.26.2.4

Webb, S., Holford, J., Hodge, S., Milana, M., \& Waller, R. (2017). Lifelong learning for quality education: exploring the neglected aspect of sustainable development goal 4. International Journal of Lifelong Education, 36(5), 509-511. https://doi.org/10.1080/02601370.2017.1398489

Zagorodnya, A. A. (2018). Continuing education as a direction of modernization of training of future specialists in the economic sector of Ukraine: the experience of the Republic of Poland. In: Conceptual ways of development: pedagogical sciences. Proceedings of the II International Scientific and Practical Conference (Lviv, May 11-12, 2018) (edited by authors) (pp. 57-61). Kherson, Ukraine: Molody Vcheny.

Ziani, A.-K., Elareshi, M., \& Al-Jaber, K. (2018). Journalism Education in the GCC Region: University Students' and Professionalism Perspectives. Media Watch, 9(1), 52-68. https://doi.org/10.15655/mw/2018/v9i1/49275

\section{Appendix A.}

\section{Questionnaire for the Respondents}

Dear respondents! Please assess the importance of acquiring the skills of the journalistic profession within lifelong learning. Thank you in advance for your candid answers.

\begin{tabular}{llllll}
\hline Item No. & Skills & Significance & & \\
\cline { 3 - 5 } & & $\mathbf{0}$ & $\mathbf{1}$ & $\mathbf{2}$ & $\mathbf{3}$ \\
\hline 1 & critical-analytical thinking & & & \\
2 & communicative skills & & & \\
3 & creativity & & & \\
4 & social tolerance & & & \\
5 & innovation & & & \\
6 & digital literacy & & & \\
7 & visual literacy & & & \\
8 & professional independence & & & \\
9 & professional responsibility & & & \\
10 & fact-checking & & & \\
\hline
\end{tabular}

Note: 0 - not significant, 1 - low significance, 2 - medium significance, 3 - high significance

\section{Copyrights}

Copyright for this article is retained by the author(s), with first publication rights granted to the journal.

This is an open-access article distributed under the terms and conditions of the Creative Commons Attribution license (http://creativecommons.org/licenses/by/4.0/). 